Creative Commons User License: CC BY-NC-ND

Abstracted by: EBSCOhost, Electronic Journals Service (EJS),

Google Scholar, Journal Seek, Scientific Commons,

Food and Agricultural Organization (FAO), CABI and Scopus

http://eoi.citefactor.org/10.11226/v26i1
Journal of Agricultural Extension

Vol. 26 (1) January, 2022

ISSN(e): 24086851; ISSN(Print); 1119944X

http://journal.aesonnigeria.org

http://www.ajol.info/index.php/jae

Email: editorinchief@aesonnigeria.org

\title{
Uptake of Conservation Agriculture Technology through Farmer Field Schools in the Democratic Republic of Congo and Mozambique
}

https://dx.doi.org/10.4314/jae.v26i1.6

\section{Inacio M. Cipriano}

Department of Agrarian Sciences, ESUDER, University of Eduardo Mondlane, Mozambique \& Department of Biotechnology, University of Kisangani, Republic Democratic of Congo

Email: cipriano12cipriano@gmail.com; +258826905168

\section{Didy O. Onautsu}

Department of Biotechnology, University of Kisangani, Republic Democratic of Congo

Email: didyonautshu@yahoo.fr ; +243822009010

\section{Titki D. Tarassoum}

Department of Agrarian Sciences, ESUDER, University of Eduardo Mondlane, Mozambique Email: ttarassoum@gmail.com; +258848402527

\section{Idris I. Adejumobi}

International Institute of Tropical Agriculture (IITA), Nigeria \& Department of Biotechnology, University of Kisangani, Republic Democratic of Congo

Email: adejumobiidris@yahoo.com;+2349066378488

\section{Bily A. Bolakonga}

Department of agricultural economics, Yangambi Institute of Agronomic Sciences, Republic Democratic of Congo

Email: bolakonga_ilye@yahoo.fr; +243812519719

\section{Abstract}

The study assessed the levels of usage of conservation agriculture technology in Kisangani, Democratic Republic of Congo and Angonia, Mozambique. A structured questionnaire was randomly administered to 192 farmers in each study site to collect data through a multistage sampling process. The study employed descriptive statistics and multinomial logistic regression to examine possible relationships among the study parameters. The results showed that land size used for conservation agriculture was a significant predictor in both study sites. Farmers' intention to adopt depended on the services of vulgarisation of conservation agriculture technology. The results further showed that Kisangani farmers do not use the threeconservation agriculture technology at the same time, but they use crop rotation (54\%). However, farmers use the three technologies (30\%) simultaneously and soil cover (38\%) in Angonia. The results suggest that efforts to promote adoption in Kisangani should be based on equal provision of extension services in all locations, and that the current farmer field schools (FFS) approach should be redesigned for contextualisation. For both study sites, the results imply that the use of FFS should be adapted to the use of farmer-to-farmer extension services, which can improve the upscaling of conservation agriculture to increase food security in a sustainable manner. 
Creative Commons User License: CC BY-NC-ND

Abstracted by: EBSCOhost, Electronic Journals Service (EJS), Google Scholar, Journal Seek, Scientific Commons,

Food and Agricultural Organization (FAO), CABI and Scopus

http://eoi.citefactor.org/10.11226/v26i1
Journal of Agricultural Extension

Vol. 26 (1) January, 2022

ISSN(e): 24086851; ISSN(Print); 1119944X

http://journal.aesonnigeria.org

http://www.ajol.info/index.php/iae

Email: editorinchief@aesonnigeria.org

Keys words: Adoption of conservation agriculture, minimum soil disturbance, soil cover, crop rotation, farmer field schools, farmer-to-farmer extension.

\section{Introduction}

Uptake of improved agricultural technology practices in Africa has been reported to be lagging (Brown, Llewellyn, et al., 2018; Mutyasira et al., 2018; Ngoma et al., 2021). This has led many researchers to question the functionality of the present agricultural systems and methods in use (Brown, Llewellyn, et al., 2018; Jena, 2019). Several approaches have been undertaken to spread modern farming technologies, including farmer field schools (FFS), which help farmers to make choices and decisions to enhance the uptake of modern agricultural innovations through facilitative training (Imam et al., 2021; van den Berg et al., 2020, 2021). However, the slow adoption of agricultural technologies has also cast doubt on the FFS model's efficacy due to its undesirable outcomes.

FFS has been used in several parts of the world to transfer different technologies, especially in Africa. One technology that is been promoted through FFS with farmers is sustainable agricultural practices, specifically conservation agriculture (CA). CA is a system of production based on three interrelated agronomic practices namely minimum or no mechanical soil disturbance, permanent soil cover to protect soil and water conservation and diversified crops grown in rotation or association with legume crops (Bourne et al., 2021; Brown, Llewellyn, et al., 2018; Mutyasira et al., 2018). The implementation of CA has generally been based on the argument that the quality of the soil has diminished due to the intensification of agriculture to increase food production in order to feed the growing population (Ngoma et al., 2021).

On the one hand, there is an ongoing debate about the benefits of $\mathrm{CA}$ for smallholder farmers (Brown, Nuberg, et al., 2018; Mutyasira et al., 2018). On the other hand, there are studies that call into question the benefits, feasibility and relevance of CA from the perspective of farmers (Bourne et al., 2021) as well as studies that highlight the limited uptake of CA by farmers (Brown, Llewellyn, et al., 2018; Mutyasira et al., 2018). Despite this, CA is being promoted in various countries using FFS, and its adoption is a high priority on the policy and research agendas in most SSA countries (Mutyasira et al., 2018).

In the past, studies attempted to analyse socioeconomic characteristics to explain the differences between farmers who adopt and those who do not in a single context (Hammond et al., 2020; Mutimura et al., 2018; Serebrennikov et al., 2020). This is leading to an inaccurate perception of agricultural innovation uptake. Moreover, few research approaches have focused on studying adoption to undertake a comparative study across different contexts in SSA to contribute to knowledge of where, how and for whom CA is appropriate (Mutimura et al., 2018). In addition, no previous study has investigated adoption to estimate the uptake of CA technology in Kisangani in the Democratic Republic of Congo and Angonia in Mozambique comparatively to inform the policy and decision makers. The study thus, assessed (1) the effectiveness of extension services on conservation agriculture, (2) levels of usage of CA technology and (3) factors influencing adoption of CA technology and redefines 
Creative Commons User License: CC BY-NC-ND

Abstracted by: EBSCOhost, Electronic Journals Service (EJS), Google Scholar, Journal Seek, Scientific Commons,

Food and Agricultural Organization (FAO), CABI and Scopus
Journal of Agricultural Extension

Vol. 26 (1) January, 2022

ISSN(e): 24086851; ISSN(Print); 1119944X

http://journal.aesonnigeria.org

http://www.ajol.info/index.php/jae

Email: editorinchief@aesonnigeria.org

adoption method to be used for successful implementation of CA technology in both countries.

The study employed the unified theory of acceptance and use of technology theoretical framework to assess the uptake of CA (Venkatesh et al. (2016). The UTAUT has four predictors of users' behavioural intentions (Fig 1): Performance expectancy: the degree to which the individuals believe that by using the system, their results will improve if compared to previous ones. For example, an increase in productivity or soil fertility in the field can be attributed to using new technology. Effort expectancy is the degree of ease associated with the use of the new technology. The other factor is social influence- the degree to which an individual is able to judge which system or technology he or she should follow. It is an individual judgement based upon the advantages of current practices over the past as well as social pressure in a given context. The last determinant is facilitating conditions- the degree to which an individual believes that he or she is equipped technically to support the use of the new technology. Additionally, UTAUT determines that gender, age, occupation, education and experience are moderators in the model, which means that they influence the predictors to form behavioural intentions as well.

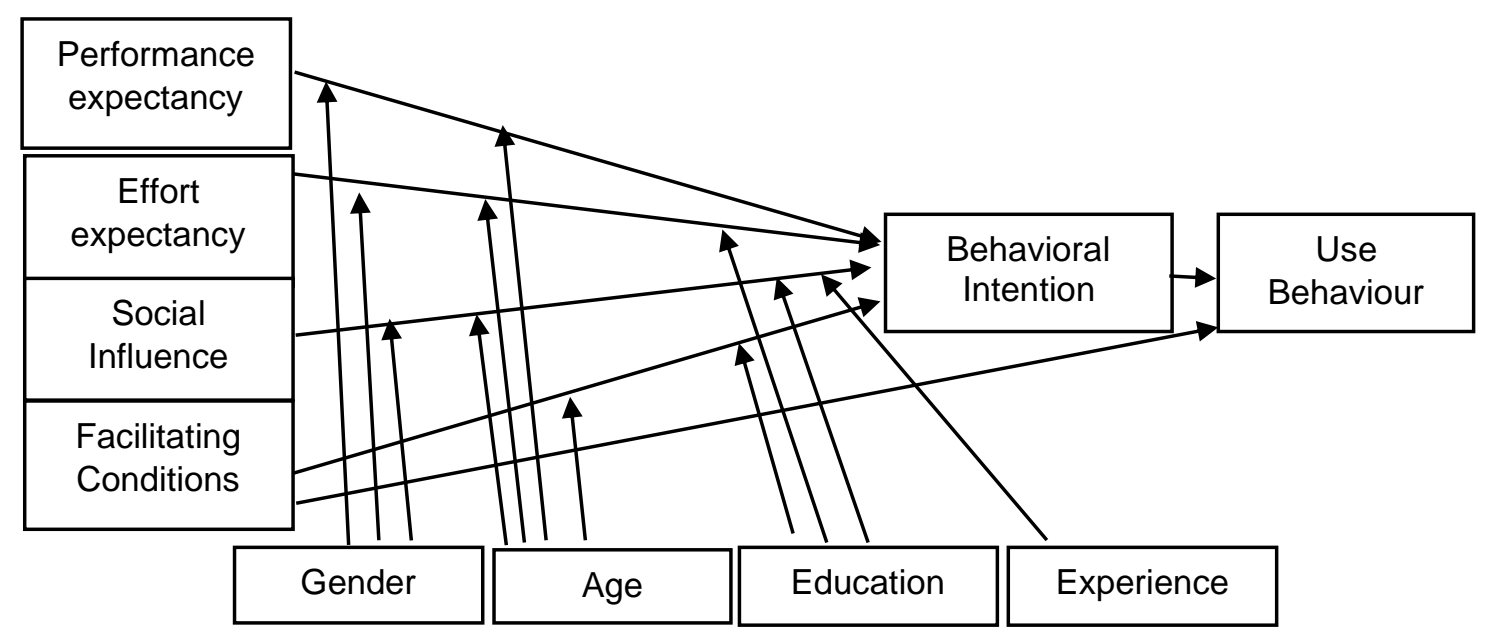

Figure 1: Adapted unified theory of acceptance and use of technology (UTAUT) (Venkatesh et al., 2016)

\section{Methodology}

The data used in this study were drawn from a recent farm household survey conducted from August 2020 to January 2021 in Kisangani (DR Congo) and Angonia (Mozambique) respectively. Angonia (latitude $14^{\circ} 43^{\prime} 1.2^{\prime \prime} \mathrm{S}$, longitude $34^{\circ} 22^{\prime} 1.20^{\prime \prime}$ East) is a district situated in the northern part of Tete Province in the central region of Mozambique. Kisangani (latitude $0^{0} 30^{\prime} 55^{\prime \prime}$ North, longitude $25^{\circ} 11^{\prime} 27^{\prime \prime}$ East) is the north-eastern city of the Democratic Republic of Congo (Muvatsi et al., 2021). Both sites present varied climatic conditions. While in Kisangani it rains all along the year with January having the least precipitation of $83.8 \mathrm{~mm}$, in Angonia it only rains from late November to early April, with the rest of the year being the dry season (Ministério da agricultura, 2016). The rainfall ranges from 1200 to $1800 \mathrm{~mm}$ per year in both sites. 
Creative Commons User License: CC BY-NC-ND

Abstracted by: EBSCOhost, Electronic Journals Service (EJS),

Google Scholar, Journal Seek, Scientific Commons,

Food and Agricultural Organization (FAO), CABI and Scopus
Journal of Agricultural Extension

Vol. 26 (1) January, 2022

ISSN(e): 24086851; ISSN(Print); 1119944X

http://journal.aesonnigeria.org

http://www.ajol.info/index.php/jae

Email: editorinchief@aesonnigeria.org

Using the formula recommended by Adam (2020), a total sample size of 384 households (192 on each site) was surveyed across different villages both in Kisangani and Angonia (Table 1). A multistage sampling procedure with face-to-face interviews was conducted to arrive at the final respondent for the study. First, geographic regions were selected based on the ease of access to farmers and clusters were randomly chosen. Second, associations of farmers in the targeted regions were selected according to the kind of crops they grow in their fields. The groups were also randomly selected. Third, the selection was done during the administration of a close-ended questionnaire using simple random sampling (Ntshangase et al., 2018). This process ensured representation of the sample, making it unbiased and reliable (Ntshangase et al., 2018).

\section{Table 1: Locations and number of sample}

\begin{tabular}{|c|c|c|c|}
\hline (Mozambique)- & Frequency & $\begin{array}{lll}\begin{array}{l}\text { Kisangani } \\
\text { Localities }\end{array} & \text { (DR } & \text { Congo) } \\
\end{array}$ & - Frequency \\
\hline Dziwanga $30 \mathrm{~km}$ & 32 & Road Banalia Km 25-42 & 57 \\
\hline Gua $7 \mathrm{~km}$ & 17 & Road Ituri Km 23 & 19 \\
\hline Makwanguala $25 \mathrm{~km}$ & 65 & Road Lubutu Km 26 & 36 \\
\hline Silawila 45 & 17 & Road Elephant Km 12-17 & 8 \\
\hline Zioa $37 \mathrm{~km}$ & 61 & Road Seminaire Km 12-23 & 72 \\
\hline Subtotal & 192 & Total & 192 \\
\hline Total & & 384 & \\
\hline
\end{tabular}

Data collection was carried out based on a structured questionnaire and on-farm observations. On-farm observations consisted of assessing management practices on planting systems, land preparation, and use of tillage and its equipment. The questionnaire was based on the structure of the three principles of $C A$, field management before and after harvesting, benefits and challenges of CA, crop system, land preparation, frequency of extension activity, reduced tillage equipment, soil quality experience in the field, etc.

A multinomial logistic regression model (MLRM) was employed to identify predictor variables associated with the adoption of CA: minimum soil disturbance, soil cover and crop rotation (Table 2). The MLRM then generated coefficients (its standard errors and significance levels), which were used to predict a logit transformation of the probability of the adoption of CA. Using the variables in Table 2, a linear model was first run to check the multicollinearity and fitness of the model. The fitness of the model was determined using the chi-square of Pearson and Deviance that the SPSS package generates after the command. The model then tested with a $p$ value of 0.633 in Kisangani and 1.00 in Angonia, indicating that the model fitted the data well. Equation 1 also represents the model and shows how the predictors were computed in the model. 
Creative Commons User License: CC BY-NC-ND

Abstracted by: EBSCOhost, Electronic Journals Service (EJS),

Google Scholar, Journal Seek, Scientific Commons,

Food and Agricultural Organization (FAO), CABI and Scopus

http://eoi.citefactor.org/10.11226/v26i1
Journal of Agricultural Extension

Vol. 26 (1) January, 2022

ISSN(e): 24086851; ISSN(Print); 1119944X

http://journal.aesonnigeria.org

http://www.ajol.info/index.php/jae

Email: editorinchief@aesonnigeria.org

Table 2: Nature of variables used in analysis

\begin{tabular}{|c|c|c|c|}
\hline & variables & $\begin{array}{c}\text { Variable } \\
\text { description/type }\end{array}$ & Descriptions/Unity \\
\hline $\begin{array}{l}\text { Dependent } \\
\text { variables }\end{array}$ & $\begin{array}{l}\text { Minimum soil disturbance } \\
\text { Soil cover } \\
\text { Crop rotation or intercropping }\end{array}$ & Ordinal & $\begin{array}{l}1=\text { use; } 0=\text { doesn't use } \\
1=\text { use; } 0=\text { doesn't use } \\
1=\text { use; } 0=\text { doesn't use }\end{array}$ \\
\hline \multirow[t]{2}{*}{$\begin{array}{l}\text { Independent } \\
\text { variables }\end{array}$} & $\begin{array}{l}\text { Farming experience } \\
\text { Land size of CA } \\
\text { Land size for conventional } \\
\text { system }\end{array}$ & $\begin{array}{l}\text { Continuous } \\
\text { Continuous } \\
\text { Continuous }\end{array}$ & $\begin{array}{l}\text { Years } \\
\text { Hectares } \\
\text { Hectares }\end{array}$ \\
\hline & Formal education & Ordinal & $\begin{array}{l}0=\text { No school attended; } 1=1-4 \\
\text { year; } 2=4-8 \text { years; } 3=9-12 \\
\text { years; } 4=\text { Tertiary-college }\end{array}$ \\
\hline
\end{tabular}

$p_{m i}=\left(\frac{e^{\left(Z_{m i}\right)}}{\sum_{m=0}^{M-1} e^{\left(z_{m i}\right)}}\right) ; m=0 \ldots \mathrm{M}-1$

$i=$ each case of a sample size $n ; M=$ Total quantity of categories of the polytomous dependent variable; $m=$ Number of categories coded from 0 to $M-1 ; Y i=$ Polytomous dependent variable $\left(Y_{i}=0 ; 1 ; 2 ; \ldots\right) ; Z_{0 i}=$ Logit of category 0 (reference category); $Z_{m i}=$ Logit; $p_{m i}=$ Probability of occurrence of uptake of $\mathrm{CA} ; B=$ Constant; $B_{m k}=$ Regression coefficients; $X_{i k}=$ Independent variable $k$ (Predictor $k$ ) metric or dichotomous.

\section{Results and Discussion}

\section{The Impact of Extension Assistance on Conservation Agriculture}

In Kisangani County (DR Congo), 16\% reported not receiving the extension assistance and $39 \%$ had only irregular visits or only when the extension department planned a certain training, as a farmer reported: "They come because they want to eat their money (stipend) and want to justify it by coming here". The result suggests that there is a problem with extension assistance in Kisangani county (DR Congo). On the government side, it appeared that extension service was happening by chance and not planned. The result also shows that extension is almost done effectively only on one axis of Banalia (30\%), usually once a month. The route of this axis is acceptable and the extension is mainly done by non-government organisations. The danger of relying on private extension alone is that most companies may not address the broader concerns of farmers. Organisations may focus on a single crop, neglecting that farmers engage in many farming activities (Davis \& Franzel, 2018). In addition, organisations may give priority to farmers with the resources to meet the technologies and the value of the crops. As such, extension may not be equitable to all farmers to access information. In this regard, the broader vision of poverty reduction may not be addressed.

Contrasted with the Kisangani results, the overall response in Angonia county (Mozambique) to the above question was positive. Eighty-four percent $(84 \%)$ of the 192 farmers reported having technical assistance each month, whether once or twice 
Creative Commons User License: CC BY-NC-ND

Abstracted by: EBSCOhost, Electronic Journals Service (EJS),

Google Scholar, Journal Seek, Scientific Commons,

Food and Agricultural Organization (FAO), CABI and Scopus
Journal of Agricultural Extension

Vol. 26 (1) January, 2022

ISSN(e): 24086851; ISSN(Print); 1119944X

http://journal.aesonnigeria.org

http://www.ajol.info/index.php/jae

Email: editorinchief@aesonnigeria.org

a month, depending on the demand of each farmer, group situations, and rainy seasons. However, none of the farmers surveyed reported not having the extension assistance. Compared with Kisangani, extension service in Angonia is mainly coordinated by the government. According to the adapted unified theory of acceptance and use of technology (UTAUT), extension service is one of the facilitating conditions that enhance farmers' ability to use the technologies (Venkatesh et al., 2016). In this regard, Kisangani farmers require government enforcement in extension services, particularly as the primary service provider. Hence, the adoption of technologies is dependent on extension services, an educational process that supports farmers with technical advice to improve agricultural performance. Farmers adopt new technologies after they have clearly seen their benefits (Rogers et al., 2019). Unfortunately, many Kisangani farmers were not exposed to the benefits of CA technology. As a result of their lack of exposure, many farmers were unable to even consider an adoption situation.

\section{Level of Use of Conservation Agriculture in Field Management}

In line with the assessment of field management, farmers were asked about their land preparation methods, planting systems and crop straw handling before and after harvesting. Concerning planting techniques (Table 3), in Kisangani county (DR Congo), the results showed that $94 \%$ of the farming population practiced monoculture (single crop). This technique was common in the study areas because of the types of crops (rice, cassava, veggies, and sometimes maize) cultivated by farmers. Farmers lack basic knowledge on how to produce their crops using CA practices because extension services are scarce in the area.

In Mozambique, 99\% of farmers adopted crop rotation. This technique is used in monoculture, whereby grain legumes are followed by two seasons of cereals, a standard crop rotation. However, it was observed that farmers exhibited resistance to planting legumes in large areas of their land due to market challenges. As a result, it was common to observe rotations of common beans (Phaseolus vulgaris) or soya beans, against maize due to their market outcomes. The results further show that $46 \%$ of farmers do mix crops, a very common practice used even by farmers who were not included in the group of farmers promoting conservation agriculture.

The overall result of the field management showed that, on average, $98 \%$ of farmers in both study sites use manual hoes for farming, with an insignificant number of farmers in Mozambique using ox-driven ploughs (Table 3). CIAT, the World Bank, CCAFS and LI-BIRD (2017) have observed that the use of traditional tools constitutes one of the reasons why most farmers fall under food insecurity. The problem of food insecurity is exacerbated in locations where the population has increased and arable land has been depleted. 
Creative Commons User License: CC BY-NC-ND

Abstracted by: EBSCOhost, Electronic Journals Service (EJS),

Google Scholar, Journal Seek, Scientific Commons,

Food and Agricultural Organization (FAO), CABI and Scopus

http://eoi.citefactor.org/10.11226/v26i1
Journal of Agricultural Extension

Vol. 26 (1) January, 2022

ISSN(e): 24086851; ISSN(Print); 1119944X

http://journal.aesonnigeria.org

http://www.ajol.info/index.php/jae

Email: editorinchief@aesonnigeria.org

Table 3: Farmers' planting techniques in Kisangani (DR Congo) and Angonia (Mozambique)

\begin{tabular}{lcc} 
& Kisangani (DR Congo) & Angonia (Mozambique) \\
\hline Planting & Response rate & Response rate $(\mathbf{n}=\mathbf{1 9 2})$ \\
techniques & $(\mathbf{n}=\mathbf{1 9 2})$ & \\
\hline Use of crop rotation & $55.7 \%$ & $99 \%$ \\
Use of monoculture & $93.8 \%$ & $2.1 \%$ \\
Use of mixed crops & $35.9 \%$ & $46.4 \%$ \\
Total & $\mathbf{6 1 . 8 \%}$ & $\mathbf{4 9 \%}$ \\
\hline
\end{tabular}

Table 4 summarizes farmers' approaches to crop residues. In Kisangani (DR Congo), $80 \%$ of farmers reported retaining residues to protect the soil, compared with 93\% in Angonia (Mozambique). The slight difference between the two sites could be explained by the fact that an estimated 19\% of farmers in Kisangani (DR Congo) burn the straws to clean up the field. Some farmers also reported that there was no need to remove the straws because crop residues readily decompose due to the prevalence of termites or are consumed by grazing cattle during the long dry season of forage scarcity in Mozambique. These phenomena explain the absence of crop residues on farmlands between the period of crop harvest and the start of the next growing season. Interestingly, the majority of farmers keep crop residues as part of conservation agriculture implementation and use. Contrary to what was found in Malawi by Bouwman et al. (2021), there was no competition between humans and livestock for crop residues in the study areas. This phenomenon was not reported in any of the study sites and was only observed on rare occasions in Angonia. In essence, conflict between humans and livestock in Kisangani (DR Congo) would have no consequence because of its particularly long rainy season, resulting in an abundance of biomass and grass cover.

Table 4: Farmers on action towards crop straws in Kisangani (DR Congo) and Angonia (Mozambique)

\begin{tabular}{lcc} 
& Kisangani (DR Congo) & Angonia (Mozambique) \\
\hline Action towards crop straws parameters & Percent ( $\mathbf{n = 1 9 2 )}$ & Percent $(\mathbf{n = 1 9 2 )}$ \\
\hline Retain residues to protect the soil & 79.8 & 93.2 \\
Bale for fodder & 0.6 & 2.6 \\
Allow cattle to feed on them & 1.2 & 0.5 \\
Remove part of straws and burn & 18.5 & 1 \\
All options minus 4th option & - & 2.6 \\
Total & $\mathbf{1 0 0}$ & $\mathbf{1 0 0}$ \\
\hline
\end{tabular}


Creative Commons User License: CC BY-NC-ND

Abstracted by: EBSCOhost, Electronic Journals Service (EJS),

Google Scholar, Journal Seek, Scientific Commons,

Food and Agricultural Organization (FAO), CABI and Scopus

http://eoi.citefactor.org/10.11226/v26i1
Journal of Agricultural Extension

Vol. 26 (1) January, 2022

ISSN(e): 24086851; ISSN(Print); 1119944X

http://journal.aesonnigeria.org

http://www.ajol.info/index.php/jae

Email: editorinchief@aesonnigeria.org

\section{Level of Use of Principles of Conservation Agriculture Technology}

The rate of conservation agriculture technology's implementation by farmers is presented in Table 5 . The results showed that about $15 \%$ of the farmers in the Kisangani (DR Congo) site did not practice CA technology even after they had received orientation on CA. This could be explained by the lack of access to some areas, which renders the planning and delivery of CA extension services by the department of Agriculture. Nevertheless, a good proportion of farmers (54\%) used intercropping techniques. Table 5 shows that $30 \%$ of farmers in Angonia (Mozambique) used all the recommended techniques of CA, compared with Kisangani (DR Congo), where no farmer reported using the three principles of CA at the same time. Overall, the results show that there were many farmers in Kisangani, as well as in Angonia, who did not completely use all the CA principles. Farmers generally choose one or two CA techniques to implement on their farms. Often, the selection of CA principles is influenced by the farmers' belief in their cropping system or by their perception of the benefits of CA in terms of labour costs and expected revenues.

Umar (2014) found in Zambia that farmers were aware that allocating all their cultivated areas to CA would increase crop yields and crop incomes. Hence, they have a number of factors influencing their decision to use one or other agricultural system. For example, the perception that some crops perform well in a particular tillage system; the case of sweet potatoes and cassavas, which are believed to produce well on ridges. However, de Freitas \& Landers (2014) only found positive impacts of CA in a situation with farmers who practiced all three CA technologies, namely minimum soil disturbance, soil cover and crop rotation. In this regard, a study of the impact of CA in the study sites might provide a better evaluation in terms of outcomes as a consequence of CA practice.

Table 5: Farmers using conservation agriculture techniques in Kisangani (DR Congo) and Angonia (Mozambique)

\begin{tabular}{lcc} 
& Kisangani (DR Congo) & Angonia (Mozambique) \\
\hline CA technology & Percent ( $\mathbf{n = 1 9 2 )}$ & Percent ( $\mathbf{n}=192)$ \\
\hline Minimum soil disturbance & 24 & 14.6 \\
Soil cover/ stubble retention & 6.8 & 37.5 \\
Crop rotation or intercropping & 54.2 & 16.1 \\
All 1,2,3 options & - & 30.2 \\
Not using/Cannot tell/ doesn't & 14.7 & 1.6 \\
know & & \\
Total & $\mathbf{1 0 0}$ & $\mathbf{1 0 0}$ \\
\hline
\end{tabular}

Factors Influencing the Use of Conservation Adoption Technology Adoption Multinomial logistic regression was performed to verify if farming experience, formal education, and farm size used were predictors in the process of adoption of CA technology. Each category group was compared against the reference category (minimum soil disturbance). Regression coefficients were used to determine which predictors significantly discriminated between farmers who adopted soil cover and 
Creative Commons User License: CC BY-NC-ND

Abstracted by: EBSCOhost, Electronic Journals Service (EJS), Google Scholar, Journal Seek, Scientific Commons,

Food and Agricultural Organization (FAO), CABI and Scopus
Journal of Agricultural Extension

Vol. 26 (1) January, 2022

ISSN(e): 24086851; ISSN(Print); 1119944X

http://journal.aesonnigeria.org

http://www.ajol.info/index.php/jae

Email: editorinchief@aesonnigeria.org

those who adopted minimum soil disturbance, between those farmers who adopted crop rotation and those who adopted minimum soil disturbance, and between farmers who did not adopt CA technology and those who adopted minimum soil disturbance.

In Kisangani county (DR Congo), land size for CA system for crop rotation (second set of coefficients) was found to be a significant positive predictor $(b=2.437$, $\mathrm{S} . \mathrm{E}=1.171, p=0.037)$ in the model, as farmers scoring higher on this variable were more likely to adopt for soil cover than minimum soil disturbance (Table 6a). The odds ratio of 11.461 indicates that for each unit of increase in land size based on CA technology, the odds of a farmer adopting for crop rotation increased by a factor of 11.461. In other words, the more farmers increased the land size for CA technology, the more they were likely to adopt crop rotation or intercrop instead of the minimum soil disturbance increased by $11.461(1,046 \%)$ times. The final set of coefficients in Table 6a represents a comparison between minimum soil disturbance adopters and those who did not adopt it after receiving orientation on CA technology. Again, the land size of CA technology was found to be a significant positive predictor $(b=3.561$, S.E. $=1.326, p=0.007)$ in the model. The results indicate that farmers exposed to and guided by the CA technology were likely to adopt minimum soil disturbance practices.

The practice of minimum soil disturbance alone presents serious challenges to poor farmers with limited resources, as was the case in Kisangani county. This technology would be mostly unpractical because it requires the application of herbicides, which the majority of smallholder farmers cannot afford. Furthermore, in the absence of herbicides, it increases the demand for manual labour for the control of prevalent weeds, especially under the climatic conditions of Kisangani (DR Congo) (Ntshangase et al., 2018). Therefore, the adoption of minimum soil disturbance should be planned, taking into consideration the associated implementation cost. Finally, farming experience and formal education (Table 6a) were not important predictors in the model.

Table 6a: Factors impacting the uptake of conservation agriculture technology in Kisangani (Democratic Republic Congo)

\begin{tabular}{|c|c|c|c|c|c|c|}
\hline \multicolumn{2}{|c|}{ CA technology Vs. predictors variables } & B & Std. Error & Wald & df & $\operatorname{Exp}(B)$ \\
\hline \multirow{4}{*}{$\begin{array}{l}\text { Soil cover/ stubble } \\
\text { retention }\end{array}$} & Farming experience on CA & -1.628 & 1.471 & 1.226 & 1 & 0.196 \\
\hline & Formal education & -0.127 & 0.678 & .035 & 1 & 0.881 \\
\hline & Land size CA system & 1.886 & 1.235 & 2.333 & 1 & 6.596 \\
\hline & Land size conv. system & -0.558 & 0.729 & 0.586 & 1 & 0.572 \\
\hline \multirow{4}{*}{$\begin{array}{l}\text { Crop rotation or } \\
\text { intercropping }\end{array}$} & Farming experience on CA & -2.104 & 1.230 & 2.925 & 1 & 0.122 \\
\hline & Formal education & 0.003 & 0.593 & 0.000 & 1 & 1.003 \\
\hline & Land size CA system & 2.439 & 1.171 & $4.340^{*}$ & 1 & 11.461 \\
\hline & Land size conv. system & -0.623 & 0.643 & 0.940 & 1 & 0.536 \\
\hline \multirow{4}{*}{$\begin{array}{l}\quad \text { Not } \\
\text { using/Cannot tell/ } \\
\text { Doesn't know }\end{array}$} & Farming experience on CA & 0.343 & 1.329 & 0.067 & 1 & 1.409 \\
\hline & Formal education & 0.126 & 0.857 & 0.022 & 1 & 1.135 \\
\hline & Land size CA system & 3.561 & 1.326 & $7.210^{*}$ & 1 & 35.192 \\
\hline & Land size conv. system & -1.470 & 1.012 & 2.110 & 1 & 0.230 \\
\hline
\end{tabular}

${ }^{*} \mathrm{P} \leq 0.05$. The reference category is: minimum soil disturbance 
Creative Commons User License: CC BY-NC-ND

Abstracted by: EBSCOhost, Electronic Journals Service (EJS), Google Scholar, Journal Seek, Scientific Commons,

Food and Agricultural Organization (FAO), CABI and Scopus
Journal of Agricultural Extension

Vol. 26 (1) January, 2022

ISSN(e): 24086851; ISSN(Print); 1119944X

http://journal.aesonnigeria.org

http://www.ajol.info/index.php/jae

Email: editorinchief@aesonnigeria.org

In Angonia (Mozambique) context (Table 6b), the third set of coefficients represents comparisons between farmers who adopted minimum soil disturbance alone and those who adopted all three CA technologies, namely minimum soil disturbance, soil cover or stubble retention, and crop rotation or intercropping. Only land size for the CA system had a negative significant predictor $(b=-0.701$, S.E $=0.340, p=0.040)$ in the model. The results from this study suggest that farmers who used land size for CA systems were less likely to adopt all three CA technologies, but would likely adopt minimum soil disturbance. The odds ratio of 0.496 indicates that for every unit of land size used for the CA system, the odds of farmers adopting the three CA technologies changed by a factor of 0.496 . Alternatively, the more farmers increased their land size for CA technology, the more their time to adopt all three CA technologies over the minimum soil disturbance alone, would decrease by a factor of 0.496 times. The other predictors (farming experience, formal education, and conventional land size) were not significant in the model. Although farmers in Angonia County practice CA techniques at all times, they do apply these techniques to only $1 / 4$ of their fields, mainly because of a lack of economic resources for CA inputs such as herbicides. Yang \& Sang, (2020) have also observed that poorresource farmers restrict the adoption of CA technology because of economic conditions. Farmers may also refuse to adopt certain aspects of technology due to a lack of labour, a lack of land on which to implement the technology, an uneasy technology operation or a lack of better approach to communicating the three principles of CA to farmers.

Table 6b: Factors impacting the uptake of conservation agriculture technology in Angonia (Mozambique)

\begin{tabular}{llccccc}
\hline CA technology Vs. predictors variables & B & Std. Error & Wald & df & Exp (B) \\
\hline \multirow{2}{*}{$\begin{array}{l}\text { Soil cover/ } \\
\text { stubble }\end{array}$} & Farming experience on & -0.728 & 0.490 & 2.208 & 1 & 0.483 \\
retention & CA & & & & & \\
& Formal education & 0.198 & 0.311 & 0.405 & 1 & 1.219 \\
& Land size CA system & -0.025 & 0.241 & 0.011 & 1 & 0.975 \\
& Land size conv. system & 0.118 & 0.268 & 0.194 & 1 & 1.125 \\
\hline \multirow{3}{*}{$\begin{array}{l}\text { intep rotation or } \\
\text { interopping }\end{array}$} & Farming experience on & -0.883 & 0.739 & 1.428 & 1 & 0.414 \\
& FA & & & & & \\
& Formal education & 0.206 & 0.414 & 0.247 & 1 & 1.229 \\
& Land size CA system & 0.067 & 0.330 & 0.042 & 1 & 1.070 \\
& Land size conv. system & -0.520 & 0.427 & 1.481 & 1 & 0.595 \\
\hline \multirow{3}{*}{ All 1,2,3 options } & Farming experience on & -0.761 & 0.571 & 1.779 & 1 & 0.467 \\
& CA & & & & & \\
& Formal education & -0.333 & 0.359 & 0.861 & 1 & 0.717 \\
& Land size CA system & -0.701 & 0.340 & $4.234^{*}$ & 1 & 0.496 \\
& Land size conv. system & 0.234 & 0.282 & 0.693 & 1 & 1.264 \\
\hline
\end{tabular}

${ }^{*} \mathrm{P} \leq 0.05$. The reference category is: minimum soil disturbance.

\section{Redefining the Theory of Adoption of Conservation Agriculture Method Using} Farmer to Farmer Extension (F2FE)

CA should not be regarded as a "one-size-fits-all" solution (Ndah et al., 2018). Rather, it should be adapted to different farming contexts. The results of the study, combined with on-farm observations, suggest that farmers in Kisangani county do 
Creative Commons User License: CC BY-NC-ND

Abstracted by: EBSCOhost, Electronic Journals Service (EJS), Google Scholar, Journal Seek, Scientific Commons,

Food and Agricultural Organization (FAO), CABI and Scopus
Journal of Agricultural Extension

Vol. 26 (1) January, 2022

ISSN(e): 24086851; ISSN(Print); 1119944X

http://journal.aesonnigeria.org

http://www.ajol.info/index.php/jae

Email: editorinchief@aesonnigeria.org

not receive consistent extension services on CA. This is explained by the fact that the majority of farmers lacks simple skills of CA such as appropriate crop rotation or intercropping, which in other farming systems, for example, intercropping is traditional. This demonstrates the problems that CA encounters with the use of FFS, particularly in a top-down system like Kisangani. Therefore, the study suggests that scarce resources that are budgeted to assist farmers could be allocated to strengthen the farmer-to-farmer extension (F2FE) model, an alternative approach to facilitating the training of farmers by farmers (Meena et al., 2016). The F2FE approach consists of training farmers, referred to as lead farmers, on theory and practice about CA. Lead farmers are generally selected by their peers, or they are volunteers who wish to serve other farmers upon completion of their training. The approach is practical and cost-effective as farmers share skills among themselves towards self-empowerment instead of depending on irregular visits by extension agents.

A model for CA extension is herein proposed based upon the challenges observed in the present study, as summarized in Figure 2. The proposed model describes farmer-to-farmer extension through the creation of a structure of lead farmers on CA. At the centre of this approach are the lead farmers who undergo theoretical and practical training to strengthen their knowledge and skills.

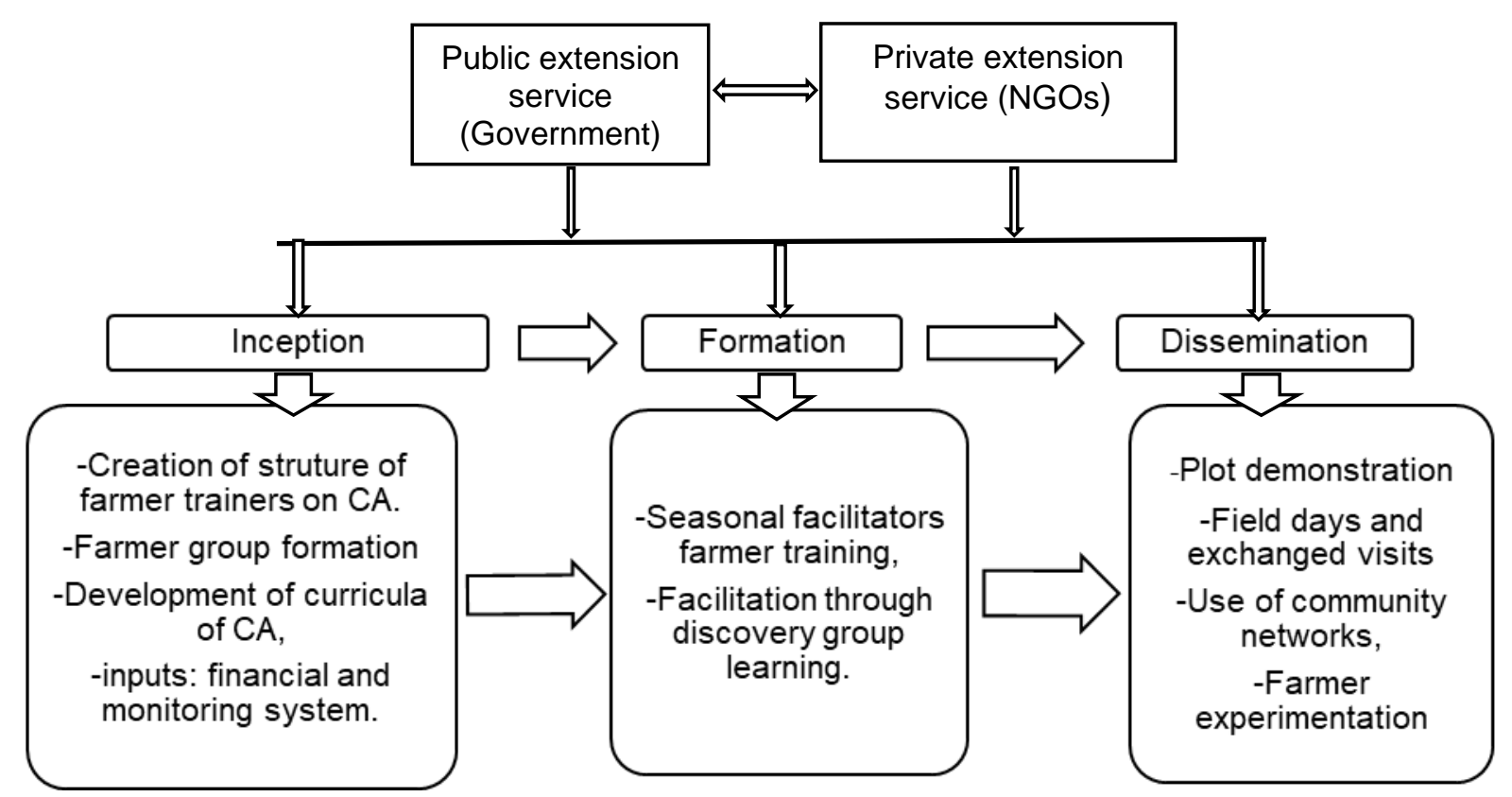

Figure 2: Proposed farmer-to-farmer extension model

The government and private sector are not excluded from the proposed model, they will serve as monitors and input suppliers as needed. The model enhances service 
Creative Commons User License: CC BY-NC-ND

Abstracted by: EBSCOhost, Electronic Journals Service (EJS), Google Scholar, Journal Seek, Scientific Commons,

Food and Agricultural Organization (FAO), CABI and Scopus
Journal of Agricultural Extension

Vol. 26 (1) January, 2022

ISSN(e): 24086851; ISSN(Print); 1119944X

http://journal.aesonnigeria.org

http://www.ajol.info/index.php/jae

Email: editorinchief@aesonnigeria.org

delivery to reach more farmers in a given period and strengthens the capacities of farmers at a reduced cost. Furthermore, farmers learn best from their peers, empower themselves through the process, and easily gain access to technology (Meena et al., 2016). In some ways, the proposed model offers a low-cost and sustainable approach, adequate to remedy the challenges uncovered in the present study.

\section{Conclusion and Recommendations}

The level of CA adoption was much lower in Kisangani, compared with that in Angonia. The lower rate of CA adoption in Kisangani was a direct result of the weak farm extension services generally provided by non-governmental agencies. In the absence of adequate extension services, farmers lack motivation or the desire to attempt CA on their own and maintain a negative perception of CA as opposed to their counterparts in Angonia. Interestingly, farmers who practiced CA at both study areas, limited CA to only small portions of their lands, understandably because of economic constraints. Therefore, land size is the predictor that influences the adoption of CA technology. The results will hopefully enhance the promotion of CA technology among farmers focusing on socioeconomic factors. Strategies to improve adoption rates could include the equal provision of extension services in all villages, the initial provision of financial incentives, and the promotion of off-farm income for the economic diversification strategy. Monitoring and evaluation of CA activities should be designed in order to constantly track implementation and outputs so as to measure the effectiveness of CA technology for farmers. Studies exploring constraints that limit farmers' adoption of all principles at the same time can add valuable information and inform the stakeholders. As a matter of policy, the study proposes the use of the F2FE approach to overcome the burden of a limited budget and ensure the sustainability and profitability of CA for farmers.

\section{Acknowledgement}

The authors wish to thank the European Union under the Intra-African Mobility (MOUNAF) project (2016-2989) for kindly supporting the study at the University of Kisangani, and the CA farmers who responded to the questionnaires analysed in the study. Gratitude also goes to Mr. François Bondele and Mr. Edson Cachepa for their technical support during data collection.

\section{References}

Adam, A. M. (2020). Sample Size Determination in Survey Research. Journal of Scientific Research and Reports, 26(5), 90-97. https://doi.org/10.9734/jsrr/2020/v26i530263

Bourne, M., de Bruyn, L. L., \& Prior, J. (2021). Participatory versus traditional agricultural advisory models for training farmers in conservation agriculture: a comparative analysis from Kenya. Journal of Agricultural Education and Extension, 27(2), 153-174. https://doi.org/10.1080/1389224X.2020.1828113

Bouwman, T. I., Andersson, J. A., \& Giller, K. E. (2021). Adapting yet not adopting? Conservation agriculture in Central Malawi. Agriculture, Ecosystems and Environment, 307. https://doi.org/10.1016/j.agee.2020.107224

Brown, B., Llewellyn, R., \& Nuberg, I. (2018). Global learnings to inform the local adaptation 
Creative Commons User License: CC BY-NC-ND

Abstracted by: EBSCOhost, Electronic Journals Service (EJS), Google Scholar, Journal Seek, Scientific Commons,

Food and Agricultural Organization (FAO), CABI and Scopus

http://eoi.citefactor.org/10.11226/v26i1
Journal of Agricultural Extension

Vol. 26 (1) January, 2022

ISSN(e): 24086851; ISSN(Print); 1119944X

http://journal.aesonnigeria.org

http://www.ajol.info/index.php/jae

Email: editorinchief@aesonnigeria.org

of conservation agriculture in Eastern and Southern Africa. Global Food Security, 17(October), 213-220. https://doi.org/10.1016/j.gfs.2017.10.002

Brown, B., Nuberg, I., \& Llewellyn, R. (2018). Research capacity for local innovation: the case of conservation agriculture in Ethiopia, Malawi and Mozambique. Journal of Agricultural Education and Extension, 24(3), 249-262.

https://doi.org/10.1080/1389224X.2018.1439758

CIAT; World Bank; CCAFS; LI-BIRD. (2017). Climate-smart agriculture (CSA) considerations. 26.

https://climateknowledgeportal.worldbank.org/sites/default/files/2019-06/CSA-inMozambique.pdf

Davis, K., \& Franzel, S. (2018). Extension and advisory services in 10 developing countries: A cross-country analysis. September, 1-61. https://www.digitalgreen.org/wpcontent/uploads/2017/09/EAS-in-Developing-Countries-FINAL.pdf

de Freitas, P. L., \& Landers, J. N. (2014). The Transformation of Agriculture in Brazil Through Development and Adoption of Zero Tillage Conservation Agriculture. International Soil and Water Conservation Research, 2(1), 35-46. https://doi.org/10.1016/S2095-6339(15)30012-5

Hammond, J., Rosenblum, N., Breseman, D., Gorman, L., Manners, R., van Wijk, M. T., Sibomana, M., Remans, R., Vanlauwe, B., \& Schut, M. (2020). Towards actionable farm typologies: Scaling adoption of agricultural inputs in Rwanda. Agricultural Systems, 183(November 2019), 102857. https://doi.org/10.1016/j.agsy.2020.102857

Imam, M. F., Wan, W., Khan, N. A., Raza, M. H., Khan, M. A. A., \& Yaseen, M. (2021). Effectiveness of agricultural extension's farmer field schools (Ffs) in pakistan: The case of citrus growers of punjab province. Ciencia Rural, 51(9), 1-10. https://doi.org/10.1590/0103-8478cr20200807

Jena, P. R. (2019). Can minimum tillage enhance productivity? Evidence from smallholder farmers in Kenya. Journal of Cleaner Production, 218, 465-475. https://doi.org/10.1016/j.jclepro.2019.01.278

Meena, M. S., Kale, R. B., Singh, S. K., \& Gupta, S. (2016). Farmer-to-Farmer Extension Model : Issues of Sustainability \& Scalability in Indian Perspective. ISEE National Seminar, 78(28-30), 78-83.

Ministério da agricultura. (2016). Anuário de Estatísticas Agrárias 2015. 66. https://www.masa.gov.mz/wp-content/uploads/2017/12/Anuario_Estatistico2016.pdf

Mutimura, M., Guthiga, P., Haug, R., Dechassa, N., Ketema, M., Hundessa, F., Tegegne, B., Kibret, K., Tana, T., Murage, A., Nyamu, G., Mburu, M., Katundu, M., Ndolo, V., Tuyisenge, J., Dusengemungu, L., Nyiransengimana, E., Myeni, L., Moeletsi, M. E., ... Mwaseba, D. (2018). Socio-economic status affecting smallholder farming and food security: A study from six case countries in Africa (Issue 727201).

Mutyasira, V., Hoag, D., \& Pendell, D. (2018). The adoption of sustainable agricultural practices by smallholder farmers in Ethiopian highlands: An integrative approach. Cogent Food and Agriculture, 4(1), 1-17.

https://doi.org/10.1080/23311932.2018.1552439 
Creative Commons User License: CC BY-NC-ND

Abstracted by: EBSCOhost, Electronic Journals Service (EJS), Google Scholar, Journal Seek, Scientific Commons,

Food and Agricultural Organization (FAO), CABI and Scopus

http://eoi.citefactor.org/10.11226/v26i1
Journal of Agricultural Extension

Vol. 26 (1) January, 2022

ISSN(e): 24086851; ISSN(Print); 1119944X

http://journal.aesonnigeria.org

http://www.ajol.info/index.php/jae

Email: editorinchief@aesonnigeria.org

Muvatsi, P., Snook, L. K., Morgan, G., \& Kahindo, J. M. (2021). The yield of edible caterpillars Imbrasia oyemensis and Cirina forda from timber trees logged on concessions in the Democratic Republic of the Congo: A contribution to managing tropical forests for multiple resources. Trees, Forests and People, 4(March), 100079. https://doi.org/10.1016/j.tfp.2021.100079

Ndah, H. T., Schuler, J., Diehl, K., Bateki, C., Sieber, S., \& Knierim, A. (2018). From dogmatic views on conservation agriculture adoption in Zambia towards adapting to context. International Journal of Agricultural Sustainability, 16(2), 228-242. https://doi.org/10.1080/14735903.2018.1447227

Ngoma, H., Angelsen, A., Jayne, T. S., \& Chapoto, A. (2021). Understanding Adoption and Impacts of Conservation Agriculture in Eastern and Southern Africa: A Review. Frontiers in Agronomy, 3(June). https://doi.org/10.3389/fagro.2021.671690

Ntshangase, N. L., Muroyiwa, B., \& Sibanda, M. (2018). Farmers' perceptions and factors influencing the adoption of no-till conservation agriculture by small-scale farmers in Zashuke, KwaZulu-Natal province. Sustainability (Switzerland), 10(2). https://doi.org/10.3390/su10020555

Rogers, E. M., Singhal, A., \& Quinlan, M. M. (2019). Diffusion of innovations. In An Integrated Approach to Communication Theory and Research, Third Edition. https://doi.org/10.4324/9780203710753-35

Serebrennikov, D., Thorne, F., Kallas, Z., \& McCarthy, S. N. (2020). Factors influencing adoption of sustainable farming practices in europe: A systemic review of empirical literature. Sustainability (Switzerland), 12(22), 1-23. https://doi.org/10.3390/su12229719

Umar, B. B. (2014). A critical review and re-assessment of theories of smallholder decisionmaking: A case of conservation agriculture households, Zambia. Renewable Agriculture and Food Systems, 29(3), 277-290. https://doi.org/10.1017/S1742170513000148

van den Berg, H., Ketelaar, J. W., Dicke, M., \& Fredrix, M. (2020). Is the farmer field school still relevant? Case studies from Malawi and Indonesia. NJAS - Wageningen Journal of Life Sciences, 92(July 2019), 100329. https://doi.org/10.1016/j.njas.2020.100329

van den Berg, H., Phillips, S., Poisot, A. S., Dicke, M., \& Fredrix, M. (2021). Leading issues in implementation of farmer field schools: a global survey. Journal of Agricultural Education and Extension, 27(3), 341-353. https://doi.org/10.1080/1389224X.2020.1858891

Venkatesh, V., Thong, J. Y. L., \& Xu, X. (2016). Unified theory of acceptance and use of technology: A synthesis and the road ahead. Journal of the Association for Information Systems, 17(5), 328-376. https://doi.org/10.17705/1jais.00428

Yang, X., \& Sang, Y. (2020). How does part-time farming affect farmers' adoption of conservation agriculture in jianghan plain, china? International Journal of Environmental Research and Public Health, 17(16), 1-12. https://doi.org/10.3390/ijerph17165983 
Creative Commons User License: CC BY-NC-ND

Abstracted by: EBSCOhost, Electronic Journals Servic

Google Scholar, Journal Seek, Scientific Commons,

Food and Agricultural Organization (FAO), CABI and Scopus

http://eoi.citefactor.org/10.11226/v26i1
Journal of Agricultural Extension

Vol. 26 (1) January, 2022

ISSN(e): 24086851; ISSN(Print); 1119944X

http://journal.aesonnigeria.org

http://www.ajol.info/index.php/jae

Email: editorinchief@aesonnigeria.org 